\title{
UJI AKTIVITAS ANTIBAKTERI EKSTRAK DAUN SURUHAN (Peperomia pellucida L. Kunth) TERHADAP Propionibacterium acnes PENYEBAB JERAWAT
}

\author{
Delladari Mayefis ${ }^{1}$, Hesti Marliza $^{2}$, Yufiradani $^{3}$ \\ 1,2,3 Laboratorium Mikrobiologi, Program Studi S1 Farmasi, \\ Sekolah Tinggi Ilmu Kesehatan Mitra Bunda Persada, \\ Email Korespondensi : dellamayefis@gmail.com
}

\begin{abstract}
ABSTRAK
Jerawat merupakan salah satu penyakit kulit yang paling umum terjadi pada semua usia, terutama pada remaja yang baru mengalami masa pubertas. Salah satu tanaman yang berkhasiat sebagai antibakteri adalah daun suruhan. Namun sampai saat ini belum ditemukan penelitian mengenai daun suruhan sebagai obat jerawat. Penelitian ini bertujuan untuk mengetahui aktivitas antibakteri ekstrak daun suruhan terhadap pertumbuhan Propionibacterium acnes penyebab jerawat. Metode yang digunakan yaitu difusi cakram (disc diffusion) dengan diberi 5 perlakuan dimulai dari konsentrasi $15 \%$, $20 \%$, 25\%, kontrol positif klindamisin dan kontrol negatif aquadest. Hasil yang didapatkan ekstrak daun suruhan mampu menghambat pertumbuhan bakter $P$. acnes dalam berbagai konsentrasi. Ekstrak daun suruhan pada konsentrasi 25\% menunjukkan respon hambatan lebih besar dibandingkan konsentrasi lainnya. Uji SPSS one way Anova menunjukkan $\mathrm{p}<0,05$ yang berarti terdapat perbedaan daya hambat pada berbagai konsentrasi ekstrak terhadap pertumbuhan P. acnes penyebab jerawat.
\end{abstract}

Kata Kunci : Peperomia pellucida L. Kunth, antibakteri, Jerawat, Propionibacterium acnes 


\title{
ANTIBACTERIAL ACTIVITY TEST OF SURUHAN LEAVES (Peperomia pellucida L. Kunth) AGAINST Propionibacterium acnes
}

\begin{abstract}
Acne is one of the most common skin diseases that occur at all ages, especially in adolescents who are just experiencing puberty. One of the plants that has antibacterial properties is the leaves of suruhan. However untill now not found research of suruhan leaf used as an acne medicine. The aim of this study was to determine the antibacterial activity of suruhan leaf extracts on the growth of Propionibacterium acnes. The method used is disc diffusion by given 5 treatments starting with a concentration of 15\%,20\%,25\%, positive control of clindamycin and negative control of aquadest.. The results obtained from leaf extracts were able to inhibit the growth of $P$. acnes bacteria in various concentrations. Suruhan leaf extracts at a concentration of $25 \%$ showed response resistance was greater than other concentrations. The one way Anova SPSS test showed $p<0.05$ which means that there were differences in the inhibitory concentration of various extracts on the growth of P. acnes that cause acne.
\end{abstract}

Keywords : Peperomia pellucida L. Kunth, antibacterial, acne, Propionibacterium acnes

\section{PENDAHULUAN}

Jerawat merupakan salah satu penyakit kulit yang paling umum terjadi pada semua usia, maupun remaja yang baru mengalami masa pubertas. Bakteri ini berperan pada pembentukan jerawat dengan menghasilkan lipase yang memecah asam lemak bebas dari lipid kulit. Asam lemak ini dapat mengakibatkan inflamasi jaringan ketika berhubungan dengan sistem imun dan mendukung terjadinya jerawat (Afifi et al., 2018).

Salah satu tanaman yang berpotensi sebagai antibakteri terhadap pertumbuhan bakteri penyebab jerawat adalah tumbuhan suruhan (Peperomia pellucida). Hasil skrining fitokimia tumbuhan suruhan ini mengandung senyawa alkaloid, flavonoid, saponin, tanin dan triterpenoid (Angelina et al., 2015).

Beberapa penelitian yang telah dilakukan sebelumnya menunjukkan bahwa tumbuhan suruhan (Peperomia pellucida L. Kunth) mempunyai potensi sebagai aktivitas analgesik, antipiretik, antiinflamasi, hipoglikemik (Sheikh et al., 2013), anti mikroba dan anti kanker (Wei, et al., 2011), dan memiliki efek analgetik (Mulyani, 2011). Tumbuhan suruhan (Peperomia pellucida L. Kunth) masih banyak digunakan sebagai obat tradisional yang berkhasiat untuk mengatasi nyeri pada rematik, asam urat, radang kulit, luka terpukul dan luka bakar ringan (Hembing, 2006). Namun, sampai saat ini belum 
ditemukan penelitian penelitian tentang tumbuhan suruhan sebagai obat jerawat. Berdasarkan latar belakang diatas dan belum ditemukan adanya penelitian daun suruhan sebagai obat jerawat maka penelitian ini dilakukan dengan tujuan untuk menguji aktivitas antibakteri ekstrak daun suruhan (Peperomia pellucida L. Kunth) terhadap Propionibacterium acnes penyebab jerawat.

\section{METODE PENELITIAN MATERIAL}

Alat

Alat-alat yang digunakan dalam penelitian ini adalah bejana maserasi, rotary evaporator, cawan porselin, Laminar air flow, autoklaf, alat gelas, Timbangan analitik, jangka sorong, incubator.

\section{Bahan}

Nutrient Agar (NA), aquadest, etanol $70 \%$, biakan Propionibacterium acnes, daun suruhan (Peperomia pellucida L. Kunth) dan clindamisin.

\section{Rancangan Penelitian \\ Pembuatan Ekstrak}

Ekstrak daun suruhan dihasilkan dengan menggunakan metode maserasi dengan pelarut etanol $70 \%$. Simplisia kering daun suruhan ditimbang sebanyak 300 gr kemudian direndam dengan pelarut etanol $70 \%$ selama 4 hari dan setiap 24 jam dilakukan penyaringan. filtrat disaring kemudian dikentalkan dengan rotary evaporator dan dilanjutkan dengan waterbath sampai benar-benar diperoleh ekstrak kental.

\section{Uji Aktivitas Antibakteri}

Biakan bakteri $P$. acnes yang digunakan pada penelitian ini merupakan baiakan yang sebelumnya telah diremajakan pada media agar miring. Sebelum dilakukan perlakuan terlebih dahulu diambil biakan P. acnes menggunakan jarum ose kemudian dilarutkan $\mathrm{NaCl}$ 0,9\%.

Uji aktivitas ekstrak daun suruhan dilakukan menggunakan metode difusi cakram dengan perlakuan diantaranya konsentrasi 15\%, 20\%, $25 \%$, clindamisin sebagai kontrol positif dan aquadest sebagai kontrol negatif. Langkah awal, bersihkan kedua tangan menggunakan alcohol $70 \%$ kemudian siapkan 4 cawan petri dan masingmasing cawan petri diberi label dalam tiap perlakuan. Selanjutnya sterilkan mulut cawan petri menggunakan lampu spiritus kemudian dipipet sebanyak 10 ml Nutrient Agar (NA) ke dalam cawan petri dan biarkan hingga memadat. Kapas ulas steril celupkan kedalam suspense $P$. acnes kemudian diusapkan pada permukaan media agar yang telah memadat selanjutnya dibiarkan selama 1-5 menit agar suspensi masuk kedalam agar.

Selanjutnya dilakukan perendaman kertas cakram pada ekstrak daun suruhan yang akan diuji dengan konsentrasi 15\%, 20\%, 25\%. Lalu celupkan juga kertas cakram pada kontrol positif dan kontrol negatif. Diangkat kertas cakram menggunakan pinset steril kemudian tunggu sampai ekstrak daun suruhan, kontrol positif dan kontrol negatif tidak menetes lagi dari kertas cakram. Kemudian diletakkan kertas cakram diatas media 
NA, diinkubasi pada suhu $37^{\circ} \mathrm{C}$ selama 24 jam dan diukur daya hambatnya berupa zona bening menggunakan alat ukur jangka sorong (mm).

\section{Analisa Data}

Analisa data dalam penelitian ini adalah analisis data deskriptif dengan penyajian data dalam bentuk tabel, serta dilakukan analisis secara statistik dengan uji One Way Anova denagn taraf signifikan 5\%.

\section{HASIL DAN PEMBAHASAN}

Setelah diinkubasi selama 24 jam kemudian diukur dan dihitung rata-rata daya hambat pertumbuhan bakteri Propionibacterium acnes sebagai respon terhadap berbagai konsentrasi ekstrak yang dapat dilihat pada tabel berikut.

Tabel 1. Hasil Pengujian Daya Hambat Ekstrak Daun Suruhan Terhadap P. acnes

\begin{tabular}{cccccc}
\hline Perlakuan & \multicolumn{5}{c}{ Diameter Zona Hambat (mm) } \\
\cline { 2 - 6 } & I & II & III & IV & $\begin{array}{c}\text { Rata- } \\
\text { rata }\end{array}$ \\
\hline $15 \%$ & 13,45 & 9,27 & 12,75 & 12,17 & 11,91 \\
\hline $20 \%$ & 10,9 & 12,4 & 18,7 & 13,92 & 13,98 \\
\hline $25 \%$ & 14.62 & 13,97 & 16,3 & 13,37 & 14,56 \\
\hline Kontrol + & 5,47 & 14,65 & 4,57 & 11,45 & 9,03 \\
\hline Kontrol - & 0 & 0 & 0 & 0 & 0 \\
\hline
\end{tabular}

Gambar 1. Zona Hambat Ekstrak Daun Suruhan Terhadap Propionibacterium acnes
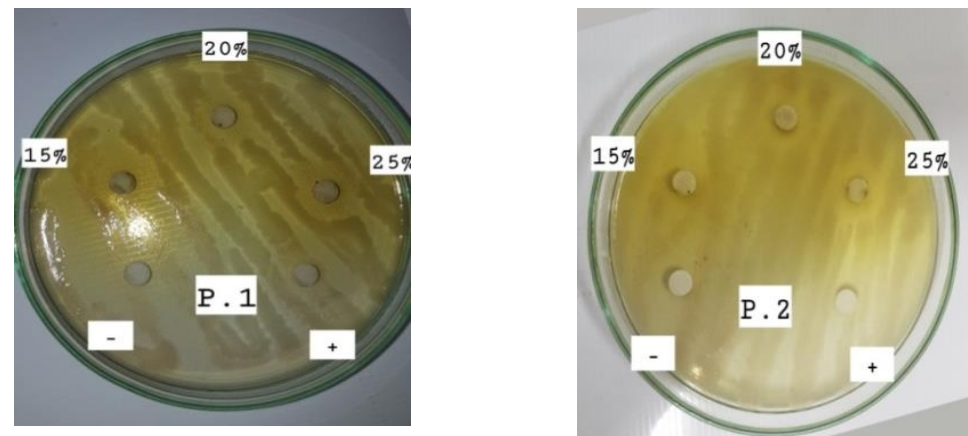


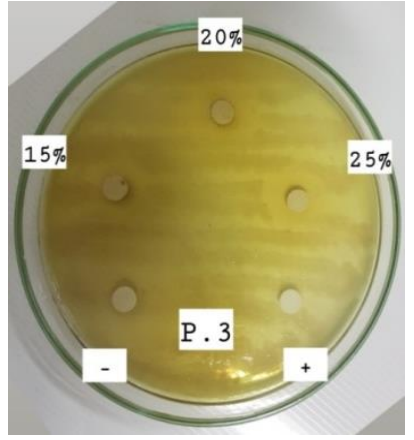

Berdasarkan tabel 1 diatas, menunjukkan bahwa diameter zona hambat pada Propionibacterium acnes terlihat berbeda dalam berbagai konsentrasi. Pada konsentrasi 15\% menunjukkan bahwa diameter zona hambat sebanyak 11,91 $\mathrm{mm}$, konsentrasi $20 \%$ sebanyak 13,98 dan konsentrasi $25 \%$ menunjukkan zona hambat sebesar 14,56 mm. sedangkan konrol positif yang berisi clindamisin diperoleh daya hambat $9,03 \mathrm{~mm}$ dan kontrol negative yang berisi aquadest diperoleh daya hambat $0 \mathrm{~mm}$ atau tidak memberikan respon hambatan.

Zona hambat menunjukkan sensitivitas antimikroba ekstrak daun suruhan (Peperomia pellucida L. Kunth) dalam menghambat pertumbuhan Propionibacterium acnes. Zona hambat terkecil terletak pada konsentrasi $15 \%$ sedangkan zona hambat terbesar terletak pada konsentrasi 25\%. Hal ini menunjukkan bahwa semakin besar konsentrasi yang diberikan maka semakin besar daya hambat terhadap pertumbuhan terhadap suatu bakteri.

Tumbuhan suruhan (Peperomia pellucida L. Kunth) memiliki spectrum luas dalam menghambat pertumbuhan suatu bakteri gram positif maupun gram negatif. Hasil penelitian sebelumnya

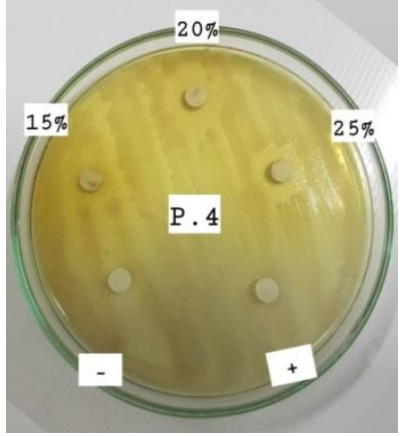

yang dilakukan oleh (Eldo, et al 2015) pada bakteri Staphylococcus aureus memiliki respon hambatan besar pada konsentrasi $75 \%$ dengan diameter sebesar $25 \mathrm{~mm}$ tergolong dalam kategori kuat. Perbedaan zona hambat pada penelitian ini terletak pada konsentrasi dan bakteri uji yang digunakan.

Perbedaan zona hambat pada Propionibacterium acnes dan Staphylococcus aureus yang terjadi karena Propionibacterium acnes termasuk bakteri bersifat anaerobic aerotoleran yang berarti bakteri ini dapat hidup walaupun tidak terdapat oksigen disekitarnya, sedangkan bakteri Staphylococcus aureus bersifat aerobic atau mikrofilik yang berarti bakteri ini masih tetap bias bertahan dalam oksigen yang rendah tetapi tidak dapat bertahan ketika tidak ada oksigen (Brooks, 2008).

Kandungan senyawa aktif dalam tumbuhan suruhan berperan sebagai zat antibakteri. Alkaloid memiliki kemampuan sebagai antibakteri dengan cara merusak dinding sel sehingga menyebabkan terhambatnya pertumbuhan bakteri dan menyebabkan bakteri mati (Retnowati et al., 2011). Selanjutnya flavonoid yang merupakan senyawa antibakteri yang memiliki 
kemampuan mendenaturasi protein sel bakteri dan merusak membran sel (Irsyad, 2013), saponin bekerja sebagai antibakteri dengan mengganggu stabilitas membrane sel bakteri sehingga menyebabkan bakterilisis (Kurniawan dan Aryana, 2015). Kemudian tanin sebgai antimikroba dengan kemampuan membentuk kompleks dengan protein polipeptida dinding sel bakteri sehingga terjadi gangguan pada dinding bakteri dan bakteri menjadi lisis (Sujatmiko, 2014).

Berdasarkan hasil uji statistic menunjukkan bahwa terdapat perbedaan pada masing-masing konsentrasi terhadap kemampuan ekstrak daun suruhan dalam menghambat pertumbuhan bakteri Propionibacterium acnes penyebab jerawat. Setiap konsentrasi memiliki perbedaan yang signifikan, sehingga tidak ada yang sama ditandai dengan nilai Sig. <0,05.

Tabel 2. Hasil Uji One Way Anova

\begin{tabular}{lrrrrrr}
\hline \multicolumn{7}{c}{ ANOVA } \\
\hline Diameter Zona & Sum of Squares & Df & Mean Square & F & Sig. \\
\hline Between Groups & 191.823 & 4 & 47.956 & 7.858 & .001 \\
\hline Within Groups & 91.544 & 15 & 6.103 & & \\
\hline Total & 283.367 & 19 & & & \\
\hline
\end{tabular}

Perbedaan konsentrasi tentu akan memberikan efek yang berbeda, karena semakin besar konsentrasi ekstrak maka semakin besar pula daya aktifnya. Jika dilihat dari kemampuan kontrol positif dengan perlakuan dari berbagai konsentrasi menunnjukkan bahwa ekstrak daun suruhan memiliki potensi besar terhadap bakteri penyebab jerawat Propionibacterium acnes, sehingga diharapkan nantinya sangat perlu dikembangkan pemanfaatan daun suruhan sebagai antibakteri khususnya bakteri penyebab jerawat.

\section{SIMPULAN}

Berdasarkan hasil penelitian yang telah ditemukan maka dapat disimpulkan bahwa :
1. Ekstrak Daun Suruhan (Peperomia pellucida L. Kunth) dapat menghambat pertumbuhan Propionibacterium acnes dengan baik pada berbagai konsentrasi yang berbeda.

2. Semakin tinggi konsentrasi ekstrak daun suruhan (Peperomia pellucida L. Kunth) maka semakin besar juga daya hambat yang dihasilkan pada bakteri Propionibacterium acnes yaitu pada konsentrasi $25 \%$.

\section{DAFTAR PUSTAKA}

Afifi, R., Erlin, E., \& Rachmawati, J. (2018). Uji anti bakteri ekstrak daun belimbing wuluh (Averrhoa bilimbi L) terhadap 
zona hambat bakteri jerawat

Propionibacterium acnes secara in vitro. Quagga, 10(01), 10-17.

Angelina, M., Amelia, P., Irsyad, M., Meilawati, L dan Hanafi, M. 2015. Karakterisasi Ekstrak Etanol Herba Ketumpangan Air (Peperomia pellucida L. Kunth). Biopropal Industri. Vol. 6 No.2:53-61

Brooks, Geo F., Janet S Butel and Stephen A. Morse. 2008. Mikrobiologi Kedokteran, alih bahasa Huriawati Hartono. Penerbit Buku Kedokteran EGC. Jakarta

Eldo, D., \& Theopilus, W. W. 2015. Uji Daya Hambat Ekstrak Etanol Suruhan (Piperumia pellucida L.H.B Kunth) terhadap Pertumbuhan Bakteri Staphylococcus aureus Secara in vitro. Biopendix, Vol. 2 No. 1 : 08-14

Irsyad, M. 2013. Standardisasi Ekstrak Etanol Tanaman Katumpangan Air (Peperomia pellucida L. Kunth). (Skripsi). Fakultas Kedokteran dan Ilmu Kesehatan. Jakarta.

Kurniawan, B., \& Aryana, W. F. (2015). Binahong (Cassia Alata L) As Inhibitor Of Escherichiacoli Growth. Jurnal Majority, 4(4).
Mulyani, D. 2011. Uji Efek Analgetik Herba Suruhan (Peperomia pellucida) Pada Mencit Putih Betina. Scientia. 1(2): 34- 38.

Retnowati, Y., Bialangi, N., \& Posangi, N. W. 2011. Pertumbuhan bakteri Staphylococcus aureus pada media yang diekspos dengan infus daun sambiloto (Andrographis Paniculata). Sainstek, 6(2).

Sheikh, H., Sikder, S., Paul, S. K., Hasan, A. R., Rahaman, M., \& Kundu, S. $\quad$ P. 2013. Hypoglycemic, antiinflammatory and analgesic activity of Peperomia pellucida (L.) HBK (piperaceae). Int $\mathbf{J}$ Pharm Sci Res, 4, 458-63.

Sujatmiko, Y. A. 2014. Aktivitas Antibakteri Ekstrak Kayu Manis (Cinnamomum burmannii B.) Dengan Cara Ekstraksi Yang Berbeda Terhadap Escherichia Coli Sensitif Dan Multiresisten Antibiotik (Doctoral dissertation, Universitas Muhammadiyah Surakarta).

Wei, S.L., Wee, W., Siong, J.Y.F., dan Syamsumir, D.F. 2011. Characterization of Anticancer, Antimicrobial, Antioxidant Properties and Chemical Compositions of Peperomia pellucida Leaf Extract. 